IFN Working Paper No. 1147, 2016

\title{
Has the Swedish Business Sector Become More Entrepreneurial than the U.S. Business Sector?
}

Fredrik Heyman, Pehr-Johan Norbäck, Lars Persson and Fredrik Andersson 


\title{
Has the Swedish Business Sector Become More Entrepreneurial than the US Business Sector?
}

\author{
Fredrik Heyman*, Pehr-Johan Norbäck* ${ }^{*}$ Lars Persson* and Fredrik \\ Andersson*
}

April 12, 2019

\begin{abstract}
Recent studies document a 30-year decline in various measures of entrepreneurship in the U.S. Using detailed Swedish employer-employee data over the period from 1990 to 2013, we find young firms to be more prominent in the Swedish business sector than in the U.S. business sector. Young Swedish firms, aged five years or less, account for more than half of all firms during this period. We also observe an increase in Swedish entrepreneurial activity for start-ups. However, since the mid-2000s, job destruction rates for young firms have been increasing, which implies a declining employment share for younger firms. Moreover, most of the job creation by young firms occurs in the expanding service sector. We discuss different explanations for why Sweden appears not to have the same strong decline in entrepreneurial activity as the U.S. has had during the last two decades. We argue that one important explanation is the economic reforms that were implemented in Sweden in the 1990s that mitigated several hurdles to entrepreneurship.
\end{abstract}

JEL: J23, K23, L26, L51

Keywords: entrepreneurship, job dynamics, matched employer-employee data, industrial structure and structural change

* Research Institute of Industrial Economics (IFN), P.O. Box 55665, SE-102 15 Stockholm, Sweden, fredrik.heyman@ifn.se, pehr-johan.norback@ifn.se, and lars.persson@ifn.se.

Acknowledgements: We thank Magnus Henrekson, Ed Lazear, Assar Lindbeck, Roger Svensson, Joacim Tåg, the Editor and two anonymous referees for their helpful comments. Charlotta Olofsson and Alexandra Allard provided excellent research assistance. Fredrik Heyman gratefully acknowledges financial support from the Swedish Research Council for Health, Working Life and Welfare (FORTE), the Torsten Söderbergs Stiftelse, the Johan och Jakob Söderbergs Stiftelse and the Jan Wallander and Tom Hedelius stiftelse. Pehr-Johan Norbäck and Lars Persson gratefully acknowledge financial support from the Jan Wallander and Tom Hedelius stiftelse and Vinnova. 


\section{Introduction}

Recent studies document a 30-year decline in various measures of entrepreneurship in the United States (e.g., Decker et al., 2014, Hathaway and Litan, 2014). Decker et al. (2014) argue that a likely reason for the decline in job dynamism in the U.S. has been the decline in the share of young firms. In this paper, we argue that this has not been the case in Sweden. Young firms have been more prominent in the Swedish business sector than in the U.S. business sector over recent decades. Young Swedish firms (aged five years or less) accounted for more than half of all firms, averaging approximately 55 percent per annum. During the same period, the share of young firms in the U.S. fell from approximately 45 percent to less than 40 percent. We also observe higher employment and job creation shares for young Swedish firms than for young U.S. firms.

When studying firm and job dynamics more in detail, we find that the share of young firms (aged five years or less) and their share of job creation in the business sector have been rather stable over the period we study. In particular, we find that it is the start-up rate that has increased in the Swedish business sector over this period. We also find that job destruction rates have increased for firms, especially for those in their first year after entry. Since the mid2000s, this increase in job destruction for the very youngest firms has led to a small decline in the employment share for young firms that have been in business for less than five years. Looking across sectors, most of the job creation by young firms in Sweden has occurred in the expanding service sector, which contrasts with the evidence for the U.S., where job creation by young firms has decreased in the service sector.

What could then explain why the Swedish business sector has been more entrepreneurial over recent decades in comparison with the U.S. business sector? And, why do the signs of less entrepreneurial activities that we find, appear later in Sweden? In this paper, we argue that the implementation of an extensive business reform package conducive to entrepreneurial activity after a severe economic crisis in Sweden during the 1980s and early 1990s is a likely explanation. These reforms removed barriers to entry and growth for new firms in several product and services markets and made the corporate ownership and labor markets more flexible. This development of the business climate in Sweden contrasts the development of the business climate in the U.S., as described by Zingales (2012), among others. He argues that the U.S. has evolved into an economy that favors incumbents over entrants, becoming pro-business instead of pro-market. We also discuss other potential 
explanations and highlight that a complementary explanation is that the Information and Communication Technology (ICT) driven structural change started later in Sweden, which could explain the stronger job creation process in the service sector in Sweden compared to the US.

The remainder of this paper is structured as follows: section 2 reviews the related literature; section 3 presents the theoretical background; section 4 describes the data and methods used for the empirical analysis; and sections 5 and 6 present the main results. In section 7, we discuss different explanations for why Sweden appears not to have the same decline in entrepreneurial activity in the business sector as the US has had during the last two decades, emphasizing the economic reforms that occurred in Sweden in the 1990s that mitigated several hurdles to entrepreneurship. Section 8 presents the study's conclusions.

\section{Related Literature}

Our paper is related to the literature on entrepreneurship and public policy. Entrepreneurship activity and its productivity crucially depend on a country's laws and policies, as argued, for instance, by Henrekson and Johansson (2009), Minnitti (2008) and Parker (2007). Shane (2009) notes that most start-ups fail and argues that policymakers should focus on reducing the incentives to create these low-probability companies. Mason and Brown (2013) use data from Scotland to suggest appropriate policies that would result in high-growth firms (HGFs). Román et al. (2013) note that several micro-institutional factors, such as social capital, will interact with macro-institutional factors, such as labor market regulations, to determine the outcome of entrepreneurship policies. Autio and Rannikko (2016) examine the growth impact of a high-growth entrepreneurship policy initiative in Finland over a six-year period. Using an eight-year panel that started two years before the initiative was launched, they find that the initiative more than doubled the growth rates of the treated firms. Mthanti and Ojah (2017) use cross-country data to compute a measure of entrepreneurial orientation (EO) using risktaking, innovativeness, and proactiveness as proxies for entrepreneurship. They find that their measure of entrepreneurial orientation is positively correlated with economic growth. We add to this literature by arguing that large-scope business reforms that are conducive to 
entrepreneurial activity can have substantial, long-lasting effects on the entrepreneurial activity in a country's business sector. ${ }^{1}$

This paper further relates to the literature on entrepreneurship and job and firm dynamics. A large literature on job and firm dynamics has shown that minor net employment changes are often a result of substantial gross job flows (Davis et al. (1997)). Haltiwanger et al. (2013) analyze the relationship between net job creation and firm size and age. They find an inverse relationship between firm size and net job growth. This result is consistent with, e.g., Neumark et al. (2011), who present evidence that small firms contribute disproportionately to net employment growth. However, when controlling for firm age, Haltiwanger et al. (2013) find that the relationship between firm size and job growth disappears. $^{2}$ A similar result is found in Heyman, Norbäck and Persson (2018). Age, rather than size, is the important characteristic for job dynamics since start-ups and young businesses create the large bulk of new jobs. Using microdata for OECD countries, Criscuolo et al. (2014) show that young firms play an important role in overall net job creation in the OECD regions but that there is also a great heterogeneity across countries in the extent to which young firms are job creators. Recent studies document a 30-year decline in various measures of entrepreneurship in the U.S. (see, e.g., Decker et al., 2014; Hathaway and Litan, 2014).

European business dynamism has been less studied. Bravo-Biosca et al. (2016) examine cross-country differences in firm growth dynamics and how they are related to different regulations and institutional settings. They show that less stringent employment protection and well-functioning financial systems are linked to a more dynamic firm growth distribution. Calvino et al. (2015) examine cross-country differences in start-up dynamics. Based on data from the DynEmp v.2 database, they find that the large majority of start-up firms do not grow but that a very small share of successful start-ups create a disproportionate percentage of the new jobs. Bijnens and Konings (2018) use Belgian data to show that Belgium's business sector has experienced a decline in dynamism that is similar to that of the US business sector.

We add to the above literature by showing that, in contrast to the US development, we observe no decline or-in the case of employment shares-a smaller and later decline in

\footnotetext{
${ }^{1}$ Henrekson and Johansson (1999) examine the evolution of the size distribution of firms over time in Sweden for a period spanning from the late 1960s to the early 1990s. They find poor development for intermediate-sized firms (10-199 employees), which suggests that institutional barriers to firm growth in the Swedish business sector were high during that period.

${ }^{2}$ See also Anyadike-Danes et al. (2015), who use cross-country data and find that adding controls for age causes the relationship between firm size and job growth to disappear.
} 
Sweden using different measures of entrepreneurial activity. We also examine the firm and employment dynamics for specific age categories, which provides us with new knowledge on business dynamism for young firms. In particular, we find an increase in start-up activity but also an increase in job destruction immediately after entry. We also find that most of the job creation by young firms occurs in the expanding service sector.

Finally, our paper also relates to the literature on regulation, institutions and entrepreneurship. Djankov (2009) surveys the literature on the relationship between entry regulations, on the one hand, and entrepreneurship and productivity, on the other hand. The presented evidence indicates economically significant effects with regard to entry rates and productivity growth. Based on a comprehensive database of European firms, Klapper et al. (2006) find that costly regulations hamper the creation of new firms, especially in industries that should naturally have high barriers to entry. Branstetter et al. (2014) evaluate the consequences of the regulatory reform in Portugal, which reduced the cost of firm entry. They report increased firm formation and employment, but mostly among 'marginal firms'. Van Stel et al. (2007) present cross-country evidence on the relationship between regulation and entrepreneurship. They find that a minimum capital requirement to start a business lowers the entrepreneurship rates, as do labor market regulations. Ciccone and Papaioannou (2007) find that countries where it takes less time to register new businesses have higher entry in industries that have experienced expansionary global demand and technology shifts. Finally, Prantl (2012) exploits a natural experiment in firm entry regulations. After German reunification, East and West Germany faced different economic conditions but were subject to the same law that imposes a substantial mandatory standard on entrepreneurs. Their main finding is that entry regulations suppressed both long-lived and short-lived entrants. ${ }^{3}$

We add to this literature by providing evidence that, since the implementation of large-scope business reforms that are conducive to entrepreneurial activity in Sweden, the Swedish business sector has become relatively more entrepreneurial in comparison with the U.S. business sector.

\footnotetext{
${ }^{3}$ See also Da Rin et al. (2011), Djankov et al. (2002) and Kneller and McGowan (2012) for evidence on the effects of taxation on industry entry and exit rates. Carroll et al. (2000; 2001) examine the effects of US tax reforms in the 1980s on the investment and hiring decisions of small businesses, finding significant effects.
} 


\section{Theoretical Background}

Why do firm start-up dynamics and entrepreneurial activity differ over time and between countries? The focus of this paper is that the cross-country variations in start-up dynamics and entrepreneurial activity reflect changes in the rules and regulations for entry and firm dynamics in different countries over time. Why then might countries regulate entry and firm dynamics? The industrial economics literature takes as its starting point the notion that unregulated markets may experience strong market failures, such as monopoly power and externalities. For instance, governments may regulate entrants to make sure that consumers buy high-quality products from "desirable" sellers; see Viscusi et al. (2005) for an overview and Arrunada (2007) and Färnstrand Damsgaard et al. (2017) for specific contributions. In this stream of literature, the differences and changes in regulations originate from changes in technology and structural factors. ${ }^{4}$

The public choice theory takes as its starting point the notion that incumbents are able to obtain regulations that create rents for themselves because they typically face lower information and organizational costs than the dispersed consumers (Stigler, 1971). Acemoglu (2008) presents a model where political power is in the hands of major producers who erect significant entry barriers against new entrepreneurs. Perotti and Volpin (2005) present a model in which incumbents seek a low level of effective investor protection to prevent potential entrants from raising capital. The incumbents succeed because they can promise larger contributions to the ruling politicians than the entrants due to the higher rents earned with less competition. Regulations may also be pursued for the benefit of politicians and bureaucrats. Politicians use regulations both to create rents and to extract them through campaign contributions, votes, and bribes (Djankov et al., 2002). In this literature, differences and changes in political power and outside forces that can change political power could then explain why entry regulations change over time and between countries.

In section 7, we will argue that, during the 1990s, Sweden undertook a large set of business sector reforms. These reforms were partly driven by a less substantial need for regulations due to technological development - but also by an increased understanding of the economic cost of extensive regulation of the business sector. We will argue that these reforms were highly influential in promoting and reigniting entrepreneurial activity in the Swedish

\footnotetext{
${ }^{4}$ See, for instance, Acs and Audretsch (2005) and Santarelli and Vivarelli (2007) for overviews of firm dynamics and market structure.
} 
business sector and could be an explanation for why business dynamism has not decreased in Sweden as it has in the US. In the next section, will we carefully document the firm dynamics and job creation and job destruction processes in Sweden in detail during the period 19902013, with a special focus on firm age.

\section{Data Description}

The empirical part of this paper is based on a comprehensive database from Statistics Sweden covering the years 1990-2013. The database includes firm, establishment, and individual data that are linked via unique identifiers. Detailed information on firms, establishments, and employees enables us to thoroughly analyze questions regarding firm dynamics.

An important issue when studying firm and job dynamics is how to credibly follow firms over time. Using organization numbers can be problematic because such numbers can change for various reasons. For instance, internal firm reorganizations sometimes result in changes in legal registration numbers, even though the employment composition remains the same. This issue complicates the identification of entrants, expanding firms, contracting firms, and shutdowns. To more reliably follow firms over time, we use additional data from Statistics Sweden (FAD by the Swedish acronym). In each year, a firm is identified by both its legal registration number as well as a survival code. Based on the employment composition in $t$ compared to that in $t-1$, firms are categorized as either remaining, new, or shutdown. The criteria for each survival type are described in detail by Andersson and Arvidson (2001). Typically, if the majority of workers remain, the firm is categorized as remaining. Each firm is assigned a unique FAD identifier. If a firm is assigned a new legal registration number but is considered remaining according to the FAD methodology, its FAD identifier does not change.

Thus, in this paper, we follow firms based on their FAD identifier, not their legal registration number. These data make it possible to identify new firm entries and firm exits, which means that we can analyze employment changes in (i) completely new units, (ii) continuing units and (iii) exiting units. ${ }^{5}$ In our analysis, we make use of the codes in the FAD data that indicate if firms are completely new or are permanently exiting. By means of these codes, employment changes should not reflect M\&A activity since these activities should give rise to changes that are not in accordance with (i) - (iii) above.

\footnotetext{
${ }^{5}$ See Andersson and Arvidsson (2011) for details on the FAD data.
} 
The FAD database also contains information on the registration year. Each firm is then divided into a firm age category corresponding to its FAD age, not its legal age. Firms registered in 1986 or before all have 1986 as their registration year, meaning that we are compelled to restrict our sample by the number of firm age categories included. For instance, it is not until the year 2000 and onward that we can safely say that a firm is actually 14 years old or older. To ensure that the results as reliable as possible, we also limit our analysis to firms with at least three employees in a given year. ${ }^{6}$

\section{Business dynamism in Sweden: A comparison with the US}

Business dynamism and the rate of business start-ups have been declining in recent decades in the U.S., as shown by Decker et al. (2014). In this section, we first highlight the differences and similarities between Sweden and the U.S. with respect to business dynamism. We then undertake a more in-depth analysis of how business dynamism has evolved in Sweden over the past two decades.

\section{Share of Activity by Young Firms}

Decker et al. (2014) provide evidence for a declining share of activity by young firms (defined as five years old or less) in the U.S. Figure 1, which is constructed from their data, shows that the share of young firms and their respective employment and job creation statistics have declined over the last two decades (for which we have comparable Swedish microdata). Decker et al. (2014) also show that this decline is secular going back to the early 1980s.

Historically, the start-up rate has been declining in Sweden as well. Figure 2, taken from Braunerhjelm and Carlsson (1993), shows that the number of new manufacturing firms, as a share of total firms, decreased by half from approximately 1950 to 1990 . Going back to as far as the 1920s, the decline is even more apparent. Our microdata do not go back further than 1990 and are not entirely comparable with the data in Braunerhjelm and Carlsson (1993). However, as shown below, our data, which, as previously mentioned, cover the last two decades, show fewer signs of a declining share of entrants. This evolution thus seems to have been halted in the early 1990s.

\footnotetext{
${ }^{6}$ The results are robust to using all firms instead of only firms with at least three employees. The only exception is results on the skewness of the firm growth distribution. This is discussed below in the sub-section on postentry dynamics.
} 
Figure 3 shows the development in Sweden over the period from 1990 to 2013 for the same measures as in Figure 1 (the share of young firms and their respective employment and job creation) but for different definitions of a young firm, which range from young firms being defined as operating for five years or less as in Decker et al. (2014) to defining young firms as start-ups (completely new firms). ${ }^{7}$

Generally, young firms appear to be more prominent in the Swedish business sector than in the business sector in the U.S. We can see that in recent decades, young Swedish firms aged five years or less accounted for more than half of all firms, steadily averaging approximately 55 percent per annum (top left panel). In the same period, the share of young firms in the U.S. fell from approximately 45 percent to less than 40 percent. There is a similar pattern for the job creation share, i.e., higher levels for young Swedish firms and more consistent over time, which is unlike the pattern in the U.S., where the share of job creation in young firms has continuously fallen since the 1980s. The evolution of the employment share of young firms in Sweden, however, does share some similarities with the development in the US. While young firms account for a larger share of employment in the business sector in Sweden, there is a downward trend in the share of employment for young firms, with the exception of that for start-ups (bottom-right panel).

\section{-- Figure 3 about here --}

Examining the contribution of different age groups among young firms in more detail reveals some interesting patterns. In Figure 4, we again graph the share of firms and the share of employment pertaining to start-ups (age zero), but then break up the age groups in Figure 3 into firms that have been in the market for one, two, three, four or five years. While the levels between the different age groups vary, each group's share of firms is rather stable over time. Employment shares show more heterogeneity; while the employment share for start-ups is again very stable over time, firms who are in their first year after entry have seen their employment shares decline significantly after the new millennium. The remaining age groups show a similar but less pronounced pattern.

\footnotetext{
${ }^{7}$ Note that we are using the same concept of job growth as in the methodology developed by Davis et al. (1997).
} 
Why do start-ups hold a stable share of employment while very young firms attract a somewhat smaller share of employment over time? Figure 5 depicts job creation and job destruction shares for firms of age 0,1 and 5. The share of job creation in start-ups (age 0) increases over time, except for the beginning of the period marking the aftermath of the Swedish crises at the beginning of the 1990s. For firms aged one year, we note that while job creation slightly declines over time, there is a lasting increase in job destruction, where the job destruction in each year exceeds job creation. As the firm age increases, the churning in terms of job creation and job destruction tapers off, becoming more similar across age groups. This is clear in the figure for firms that have been in the market for five years.

\section{-- Figure 5 about here --}

What is then the source of the observed increase in job destruction among very young firms after entry? Figure 6 shows the annual and employment-weighted firm entry and firm exit rates for firms of age 0,1 and 5. Figure 6 shows no clear trends in the annual exit rates across age groups. Figure 6 also explores and depicts the loss of employment or job destruction from firm exits (employment-weighed). Job losses due to exits in the first year after entry appear to be very important for explaining the decline in employment shares for young firms shown in Figure 3. In particular, firms with a firm age of one year are associated with a strong increase in employment losses from exits. When firms grow older, this pattern becomes less apparent. This can be seen in the figure for firms that have been in the market for five years. Finally, Figure 7 shows employment losses (job destruction) in continuing firms. After an initial peak generated by the financial crises in Sweden that occurred in the early 1990s, job losses in continuing firms show no clear trends.

The results in Figure 6 and 7 indicate that early exits appear to be the main driver of job destruction for very young firms. The fact that the overall propensity to exit appears not to have changed, while job destruction in very young firms seems to have increased over time, suggests that early exits appear to be biased towards larger entrants. This pattern is consistent with the theory proposed in Färnstrand Damsgaard et al. (2017), where more risky entry strategies (large scale entry) are associated with a higher failure rate. 
In summary, a major feature of the dynamism in the Swedish business sector stems from an increasing number of start-ups and an increasing importance of early exit (biased towards larger units). ${ }^{8}$ We now proceed to examine dynamism in broader sectors.

\section{Sector analysis}

In what sectors do young firms create new jobs? To this end, we can extend the analysis of Swedish firms by separating the effects by sector (manufacturing, service, or other). ${ }^{9}$ Due to space limitations, we now focus on firms aged five years or less, start-ups (new firms, i.e., firms at age 0 ) and very young firms (age 1).

Decker et al. (2014) report falling activity for young firms in the service sector. The pattern is the opposite in Sweden, at least with respect to employment and job creation. As shown in Figure 8, the activity of young firms is the largest in the service sector. The shares of employment, firms, job creation and job destruction of young firms are notably much higher in services than in manufacturing or other industries.

Our earlier findings on the dynamics in the entire business sector also appear at the sector level. Employment shares for young firms decline after the millennium in both the service and manufacturing sectors. Other dynamics patterns appear to be driven mainly by the service sector. For instance, job creation from start-ups stem from the service sector, and job destruction becomes increasingly important in the service sector, which is consistent with the decline in the share of employment of young firms in the service sector.

-- Figure 8 about here --

At the aggregate level, we noted that the job destruction associated with exits appeared to be the main reason for job losses after entry. We have also explored if this is the case at the sectoral level also (graphs omitted due to space constraints). Our results indicate that exits one year after entry increase over time in all sectors. While the steepness in the increase tends to be largest in the manufacturing sector, exits after one year increase from a much higher level

\footnotetext{
${ }^{8}$ Note that from the construction of our data with so-called FAD codes (which tracks the individuals working in a firm or a work place) we would argue that M\&As are likely not the reason for the pattern of increased early exits of larger entrants. In our analysis, we make use of codes in the FAD data that indicate if firms are completely new or are permanently exiting. Therefore, due to the use of these codes, employment changes should not reflect M\&A activity.

${ }^{9}$ In order to understand what type of jobs young firms have been created we have also analyzed job dynamics in terms of workers' educational background. Results are available upon request.
} 
in the service sector. In 2013, which is the last year in our data, approximately every third firm in the service sector exited after only one year in business. At older ages, exit rates become more stable in the service sector while they appear to increase over time in the two other sectors.

\section{Post-Entry Job Dynamism}

Start-ups and young firms play an important role in U.S. job creation. Evidence from the U.S. suggests that there is a distinct negative relationship between firm age and employment growth within each age group. Looking at survivors, mature firms are associated with lower rates of job creation than younger firms. While we do find similar trends in Sweden, the relationship does not seem as strong as in the U.S. Net job creation among Swedish firms seems to be rather stable for firms aged one to seven years old, unlike the U.S., where the rate drops at a higher pace. As Figure 9 illustrates, it is not until Swedish firms grow older than eight years of age that we observe significantly lower rates of net job creation. Apart from the less pronounced trend, we also observe much lower levels of job turnover in Sweden among the very youngest firms, except for the first year after entry

\section{-- Figure 9 about here --}

As for exit dynamics, the trends are similar, but the levels are again lower in Sweden. Both in the U.S. and Sweden, younger firms have a substantially higher exit rate than mature firms, and job destruction by exiting firms is higher in the U.S. than in Sweden-again with the exception of the first year after entry, where job losses from exits in Sweden are remarkably high. Thus, we find evidence that young Swedish firms also exhibit a relatively strong "up or out" dynamic.

We continue the analysis by examining the arithmetic means of employment growth at the firm level and for each age category. This exercise reveals large heterogeneity among firms. In Figure 10, we illustrate the 90th, 50th, and 10th percentiles of job growth for surviving firms by firm age for all employees. As is clear from the figure, the median growth is constant over the firm age distribution. Comparing the outliers, i.e., employment growth in the 90th and 10th percentiles, we see that the Swedish outliers are not as extreme and do not vary quite as much. In unreported results, we compare the median to the mean. As in the U.S., they are both decreasing with firm age. However, in Sweden, the median growth is higher 
than the mean growth - this is in contrast to the U.S., where the mean is consistently larger than the median.

-- Figure 10 about here -

To shed more light on the post-entry dynamics of young firms, we follow Decker et al. (2016) and investigate the firm growth rate distribution. Decker et al. (2016) find that the skewness in the firm growth distribution has declined in the US. In Figure 11, we present different measures of the skewness of the employment growth distribution in Sweden. The top panel depicts the 90-10 differential. This is the difference between the $90^{\text {th }}$ and the $10^{\text {th }}$ percentile of the employment-weighted distribution of firm employment growth rates. The top panel depicts this difference for young firms (less than or equal to five years) and mature firms (older than five years). While the skewness declined slightly in the 1990s, this trend stopped after the millennium shift. The middle panel depicts the 90-50 differential and the 50-10 differential. Since we find that the growth rate at the medium is very close to zero, the 90-50 differential will pick up the development for the $90^{\text {th }}$ percentile, while that $50-10$ differentials will pick up the development for the $10^{\text {th }}$ percentile. We note that the $50-10$ differential is falling before the millennium shift for mature firms. A potential explanation for this is the impact of the reforms in Sweden in the early 1990s, where many mature laggard firms were forced out of the market. ${ }^{10}$ Otherwise, we find a rather stable pattern both for young and mature firms. Overall, we find lower growth differentials for young firms in Sweden compared to the US. For mature firms, the levels are quite similar. However, when including firms with one or two employees also, the pattern becomes more like the pattern found in the US, that is, decreased skewness. Finally, in the bottom panel, we show that the growth rate for high growth firms $\left(90^{\text {th }}\right.$ percentile of the employment-weighted distribution) is also stable over time.

-- Figure 11 about here --

\footnotetext{
${ }^{10}$ One interpretation for the pattern in the middle panel in Figure 14 is that mature firms with low growth $\left(10^{\text {th }}\right.$ percentile) were forced out of the market, or were contracting during the restructuring process, in the years after the reforms in the early 1990s. Hence, the 50-10 differential should decrease during this period. At the same time, high growth mature firms likely benefitted from the reforms and, thus, the 90-50 ratio should increase. The combination of these movements implies a stable 90-10 differential (top panel), since the median growth in the $50^{\text {th }}$ percentile has near zero growth.
} 


\section{Is it Age Rather than Size that Matters for Dynamism?}

In our comparison of business dynamism in the U.S. and Sweden, we have focused on firm age. However, the strong correlation between how long a firm has been in business and firm size makes it difficult to distinguish between a firm size and a firm age effect regarding employment growth. Very large firms have, on average, been in business for quite a long time. Hence, observing a positive firm age and job creation relationship might in fact be a positive firm size-job creation relationship, or vice versa. Therefore, is it age or size that matters for Swedish dynamism? ${ }^{11}$ In this section, we thus investigate how firm age (measured by the number of years since start up) and firm size (measured by the number of employees) are related to each other in terms of their role in business dynamism and employment growth at the firm level.

As an illustration, Table 1 depicts net job creation as a function of firm age and size in terms of the number of employees between the years 2000 and 2013. As expected, there is positive net job creation in almost all age-size groups. Nevertheless, most of the new employment is created in small, young firms. While small start-ups create most of the employment, small firms that are 4 to 9 years of age experience the largest decline in employment, which is a sign of learning and experimenting in the "up or out" process. Looking across the diagonal, we observe significant employment creation in middle-aged, middle-sized firms. Looking across sectors (not shown), most of this net employment creation occurs in the service sector.

Finally, old-large firms experience a decline in employment, which is consistent with rapid technological development and globalization, with automation and international and domestic outsourcing shifting employment away from these firms. In summary, the overriding message of Table 1 is the fact that small start-ups create most of the new jobs in Sweden. Next, we will document this result in more detail using regression analysis.

-- Table 1 about here --

\footnotetext{
${ }^{11}$ Haltiwanger et al. (2013) examine job dynamics in the U.S. business sector and find that once they control for firm age, there is no systematic relationship between firm size and growth.
} 


\section{Effects of Firm Size and Firm Age}

To further investigate how firm size and firm age correlate with employment growth at the firm level, we estimate the following regression equation:

$$
y_{f i j t}=\alpha+\sum_{i=1,2} \beta_{i} \times \text { Ageclass }_{i}+\sum_{j=1,2,3} \gamma_{j} \times \text { Sizeclass }_{j}+\tau_{t}+\varepsilon_{f i j t}
$$

where $f$ indexes firms, $i$ indexes age classes, $j$ size classes, and $t$ years. The dependent variable $y$ represents different measures of gross job flows measured in rates (net job creation; gross job creation; gross job destruction). For simplicity, we include three size categories. Firms are defined as either small (less than 50 employees), medium (50 to 249 employees), or large (250 employees or more). For age, we use two groups. Firms aged five years or less are called young (in accordance with the classification in Decker et al., 2014), while firms older than five years are called old. We exclude young-large firms, as they might be affected by measurement error. Our estimates cover the years 2000-2013 and are based on approximately 1.4 million observations. ${ }^{12}$

Columns 1-3 in Table 2 report estimates for when the age characteristics are ignored. We observe a clear inverse relationship between firm size and job creation. Small firms are associated with a 21.3 percentage point higher gross job creation rate than large firms. The effect for medium firms is weaker, although it is still approximately 3.4 percentage points higher than that for large firms. For net job creation, we observe a similar pattern - small firms are associated with 2.5 percentage points of higher growth than large firms, and the estimate for medium firms is again lower, by 1.5 percentage points.

\section{-- Table 2 about here --}

Controlling for age characteristics, however, the estimates change dramatically, as shown in columns 4-6. The estimates for small- and medium-sized firms are now negative, which suggests that they are associated with a few percentage points lower (4.2 and 1.7, respectively) net job creation rates than large firms. The "young" dummy is, however, positive. Compared to the reference group, i.e., old firms, young firms are associated with 13.1 percentage points higher job growth.

\footnotetext{
${ }^{12}$ See also OECD (2014) for a cross-country analysis of job dynamics.
} 
The results from equation (1) include separate controls for the age and size characteristics of firms. We continue the analysis by running similar regressions; however, we now use interaction terms between the different age-size groups. This approach allows us to assess the role of firm age within size classes as well as the role of firm size within age groups. The specification is as follows:

$$
y_{f i j t}=\alpha+\sum_{i j} \delta_{i j} \text { Ageclass }_{i} \times \text { Sizeclass }_{j}+\tau_{t}+v_{f i j t}
$$

Table 3 reports the estimates for equation (2), where old-large firms are the omitted category. All groups have higher gross job creation rates than old-large firms, as shown in column 1. Young-small and young-medium firms exhibit the largest differential. Column 2, however, shows that old-large firms destroy relatively fewer jobs than all of the other groups of firms. The most interesting results, i.e., those concerning net job creation, are reported in column 3. We note that the group consisting of young-small firms accounts for the largest growth rate, making this group the most dynamic. Young-small firms are associated with approximately 9.1 percentage points higher net growth rates than old-large firms. Youngmedium firms and old-medium firms also have higher net growth rates than old-large firms, but, on the contrary, old-small firms exhibit significantly lower net growth rates.

-- Table 3 about here --

Note again that we follow the methodology of Davis et al. (1997), meaning that job creation originates with either start-ups or expanding firms. Job destruction, on the other hand, originates with either shutdowns or contracting firms. A possible explanation for the greater dynamism among young firms, as demonstrated above, is the positive contribution of entry. Hence, we repeat equations (1) and (2) but exclude entrants from the sample. As shown in Tables 4 and 5, the estimates drop drastically for young firms, suggesting that the estimates in Tables 2 and 3 indeed are driven by entrants. In fact, young firms now appear to have approximately 30 percentage points lower net growth than old firms. We also observe a change in sign for the young-small and young-medium firms. With entrants excluded, oldlarge firms do, in fact, exhibit a greater growth rate than firms in the young-small and youngmedium groups. 
From the regression exercise above, we conclude that the main determinant in business dynamism is firm age, not firm size. Entrants and young firms seem to play a major role in job creation. Similar results can also be obtained when we divide the firms into five age categories (aged 0-1 years, 2-3 years, 4-9 years, 10-13 years, or 14 years and older) and when analyzing differences across all firm age categories (results available upon request).

Thus, the firm size distribution in Sweden is not an important factor in explaining why Sweden has avoided the same decline in entrepreneurship as the US in recent decades. It is firm age and not firm size that matters for Swedish dynamism.

\section{Decline in Entrepreneurship: Why in the US but not in Sweden?}

Why does entrepreneurial activity differ over time and between countries? There are several possible sources for such differences. In this section, we will discuss some possible explanations for the observed over-time differences in entrepreneurial activity between Sweden and the US.

\section{Differences in reform patterns?}

A major difference between Sweden and the US is that a large reform package was launched in Sweden during the early 1990s. During the 1970s and 1980s, Sweden was lagging behind in productivity growth while experiencing high inflation and large budget deficits, and in the early 1990s, Sweden experienced a severe economic crisis. The 1991-1994 period was characterized by a substantial decline in GDP and increasing unemployment. Previously, during the 1980s, discussions about how to reform the Swedish welfare state had become increasingly intensive. The center-right government that came into power in 1991 was seemingly quick to implement an economic policy based on extensive deregulation in response to the 1990 crisis. Moreover, in 1993, the so-called Lindbeck Commission launched a large number of proposals to improve the efficiency of the Swedish economy (SOU 1993:16). Some of these proposals also concerned the business sector. ${ }^{13}$

Next, we describe crucial reforms that were implemented in the 1990s. We rely on detailed descriptions of the Swedish business sector and the policy reforms that affected firms

\footnotetext{
${ }^{13}$ See Lindbeck et al. (1994).
} 
in Sweden, as described by, e.g., Heyman, Norbäck and Persson (2015, 2018), and the references therein.

\section{Corporate Taxation Reforms in Sweden}

Importantly, until 1991, the Swedish tax system favored large firms and institutional ownership (e.g., pension funds and insurance companies). The 1991 tax reform and subsequent minor reforms considerably levelled the playing field for different combinations of owners and sources of financing (Davis and Henrekson, 2000 and Edquist and Henrekson, 2013). The reforms in the 1990s generated a tax system that was far more positive for individuals who wished to start, develop, and act as controlling firm owners compared with the situation in the 1970s and 1980s.

However, only examining the (marginal) tax rates to judge a tax system's effect on firm performance is insufficient. Evaluating a tax system's effect on corporate capital investment is a complicated task. Many aspects, such as the project type and the financing form, need to be considered. Here, the devil is in the details. A generally accepted method of evaluating a capital tax system is to calculate the marginal effective tax rate (METR) on capital based on the method originally presented by King and Fullerton (1984).

Devereux et al. (2002) use a simplified version of this method to compare the marginal effective corporate taxes for a number of EU countries, Japan and the US in 1982 and 2001. They show that Sweden had the second highest rate in 1982, i.e., at approximately 53 percent, but the second lowest rate in 2001, i.e., at approximately 22 percent. Hence, corporate taxes were reduced from very high levels to low levels during the reforms of the 1990s.

Using the King and Fullerton (1984) approach, Stenkula et al. (2015) examine the METR on capital for a longer period for Sweden. This study provides further evidence of Sweden's high METR for external capital (not retained earnings or institutional capital) in the 1980s (approximately 100 percent) and its significant reduction in the 1991 tax reform. These corporate and capital tax reforms created opportunities for firm development, particularly for the growth of new small firms and firm formation.

\section{The Deregulation of Product Markets in Sweden}

The center-right government that came to power in 1991 was seemingly intent on implementing an economic policy based on extensive deregulation in response to the country's economic crisis in the 1990s. However, the possibility of making such reforms, e.g., 
the deregulation of the air traffic system, the electricity market, and the postal service, had already been thoroughly investigated, and government policies had previously been outlined in government white papers prepared by the Social Democratic government in the late 1980s and early 1990s. Moreover, in 1993 (SOU 1993:16), the so-called Lindbeck Commission presented a number of proposals to improve the efficiency and functioning of markets in Sweden (Lindbeck et al., 1994). Overall, the intensity of competition increased substantially in many Swedish product markets during the 1990s.

The OECD has long calculated an index of the "knock-on" cost that regulations in the service and utility industries impose on manufacturing industries. In Heyman, Norbäck and Persson (2015), it is reported that regulations on utilities and services imposed high additional costs on manufacturing in the 1970s and 1980s, but these costs sharply decreased as Sweden began to deregulate in the late 1980s and early 1990s. Thus, beginning in the mid-1990s, the regulation costs in the services and utilities sectors were substantially lower in Sweden than the average of the EU 15, and they were even lower than such costs in the US and the UK.

The OECD has also constructed indicators to measure developments in product market regulation (PMR) across the OECD countries (Wölfl et al., 2009). Interestingly, the "barriers to entrepreneurship" category has improved the most for Sweden. Between 1998 and 2008, Swedish authorities made considerable improvements regarding licensing and permit systems and communications. Moreover, simplifications of rules and procedures were made; legal barriers were removed; and barriers to competition in network sectors and services were reduced.

Importantly, these product market reforms made it easier for new firms to enter industries and made it more difficult for old inefficient firms to remain in the product market.

\section{Labor market reforms}

The so-called Allard index measures the strictness of employment protections (Allard, 2005). This measure of the strictness of employment protections continued to increase in Sweden until the beginning of the 1990s (see Heyman, Norbäck and Persson (2015)). The average employment protection in the EU 15 countries also increased over this period, though not to the same extent as in Sweden. The US labor market continued to maintain a low level of employment protection.

Thus, the Swedish employment protection became substantially stricter in 1974 . The reason was that a new employment protection law (LAS) was implemented. The law 
mandated that employees could not be fired without reasonable cause, such as abuse or a lack of work opportunities. Insiders were also favored with respect to firing and hiring procedures through the so-called "last in, first out" rule. Temporary contracts also became limited. However, centralized bargaining for private-sector, blue-collar workers gradually broke down in the 1980s, and it was replaced by uncoordinated industry-level bargaining. Intermediate industry-level bargaining is a form of collective bargaining that should be more conducive to wage inflation. These actions made employment protection less strict. State-owned firms joined the employers' organization in 1994, which weakened the political influence in wage setting (Nycander, 2008) and made employment protection even less strict. In 1997, the Industry Agreement was concluded. The agreement included a system that continued industrylevel bargaining but with strong informal coordination based on pattern bargaining with the manufacturing sector to conclude initial wage agreements in a bargaining round. This system established a norm for wage increases for others to follow. The reformed wage-bargaining system allowed for greater individual wage flexibility (Calmfors, 2012).

A major employment protection reform that permitted staffing agencies was implemented in 1992 (Skedinger, 2010), and the regulations concerning temporary work were relaxed. This development created what is referred to as the dual Swedish labor market, with strong employment protections for regular workers and weak employment protections for temporary workers. This reform was also evident in the Allard index of employment protection, which declined significantly. Another measure of the strictness of employment protections from the OECD demonstrates that the strictness of employment protections concerning temporary contracts was significantly reduced in Sweden - from a very high level in 1985 to a very low level in 2010. However, the strictness of the employment protections concerning regular contracts remained at a relatively high level over the same period.

In summary, these reforms removed barriers to entry and growth for new firms and made the labor market more flexible. The reforms of the tax system created a system that made it far more favorable to start and develop firms compared to the situation in the 1970s and 1980s. Product market reforms were undertaken that not only made it easier for new firms to enter the industries but also made it more difficult for inefficient firms to remain in the product market. Labor market reforms were also undertaken, which increased opportunities for firms to better invest and reward human capital and for new, growing, productive firms to hire skilled labor.

This development of a new business climate in Sweden since the early 1990s seems to contrast with the development of the business climate in the U.S. as described by, among 
others, Zingales (2012). First, the US business sector did not become as regulated as the Swedish business sector in the 1970s and 1980s. Moreover, Zingales (2012) argues that, in the last decades, the U.S. has evolved into an economy that favors incumbents over entrants, becoming "pro-business" instead of "pro-market". Moreover, De Loecker and Eeckhout (2017), who examines the evolution of U.S. mark-ups from 1950, find, among other things, that the decline in job flows is driven by the rise of market power.

\section{Differences in technological development?}

An alternative explanation for why Sweden has not experienced the same slowdown of entrepreneurial activity is that the technological shift over recent decades has stimulated entrepreneurship in Sweden but not in the U.S. In particular, one could argue that technological development typically first occurs in the U.S. and then in Sweden, which would imply that the Swedish business sector, as a result, will be less entrepreneurial in the future. This explanation seems consistent with the high entrepreneurial activity we document in the Swedish service sector in comparison to the US service sector. Thus, it might be that the US has been early in switching into a more service sector dominated economy and that Sweden soon will follow the US in facing a slowdown in entrepreneurial activity.

However, Sweden has been in the forefront of the ICT-driven industrial reorganization. For instance, according to EU's "Digital and society index", Sweden ranks as number two, following Denmark, in Europe. ${ }^{14}$ In the World Economic Forum's "The Networked Readiness Index", Sweden ranks as number three after Singapore and Finland ${ }^{15}$. Thus, the later ICT development in Sweden does not seem to be the main explanation of the difference in the development in business dynamism in Sweden and in the US.

\section{Differences in changes in the share of immigrants?}

Another potential explanation is that immigrants are more likely to start new businesses and that immigration flows have decreased in the U.S., while immigration flows have been increasing in Sweden during the period under study. However, this explanation is unlikely, since immigrants in Sweden are underrepresented as owners of firms with employees and overrepresented as self-employed. ${ }^{16}$

\footnotetext{
${ }^{14}$ European Commission (2016), The Digital Economy and Society Index, https://ec.europa.eu/digital-singlemarket/en/desi.

15 World Economic Forum (2015), The global information technology report 2015, http://www3.weforum.org/docs/WEF_Global_IT_Report_2015.pdf.

${ }^{16}$ Only approximately $13 \%$ of all firms with 0-49 employees have a foreign-born owner (Tillväxtanalys (2012)), whereas Alden (2014) shows that most immigrant groups are overrepresented as self-employed.
} 
Differences in changes in age structures or in population growth?

Yet another explanation is that the older societies become, the less entrepreneurial they are, and the age structure in the U.S. may have changed in such a way that the U.S. is now less prone to entrepreneurship compared to Sweden. Lazear et al. (2014) analyze the relationship between demographics and entrepreneurship using a human capital framework. Based on cross-country data from the Global Entrepreneurship Monitor, they find that a onestandard-deviation decrease in the median age of a country increases the rate of entrepreneurship by 2.5 percentage points, which is approximately 40 percent of the mean rate.

This seems to be a potential part of the explanation for the slowdown of the entrepreneurial activity in the US. Nevertheless, we see no evidence of a decrease in entrepreneurial activity is Sweden despite an aging population. The median age has increased in Sweden from 38.4 years in 1990 to 40.7 years in 2010. The corresponding numbers for the US are 32.9 in year 1990 and 37.2 in $2010 .{ }^{17}$

What role do population and working age population growth play for the evolution of start-up rates in Sweden? Karahan et al. (2016) suggested that demographic shifts in the growth rates of the labor supply are important factors behind the declining start-up rates in the US. They show empirically that the decline in growth rates of the labor supply explains a significant share of the startup-up decline in the US during the last 30 years. While a detailed empirical analysis is beyond the scope of this paper, we have correlated Swedish start-up rates during the period of 1996-2013 with different measures of the labor supply. Using time-series data on growth in the Swedish labor force and the Swedish working age population, we find no clear correlations. ${ }^{18}$ However, it should be noted that the growth in the Swedish labor force and the Swedish working age population has been stable over the period compared to the US, where these factors have varied more. Thus, Sweden's high start-up rates are likely supported by a stable population and labor force growth. A stable population and labor force growth might, however, mask substantial regional differences.

\footnotetext{
${ }^{17}$ https://www.statista.com/statistics/375459/average-age-of-the-population-in-sweden/ and https://www.statista.com/statistics/241494/median-age-of-the-us-population/.

${ }^{18}$ Analysis available on request from the authors.
} 


\section{Summary and Conclusions}

We take as our point of departure the more than 30-year decline in entrepreneurship dynamism and activity by young firms documented in the U.S. (see, e.g., Decker et al., 2014 and Hathaway and Litan, 2014). Using detailed Swedish employer-employee data over the period of 1990-2013, we observe no decline or a smaller and later decline in Sweden for different measures of entrepreneurial activity. In particular, we find an increase in the start-up activity. We also find an increase in job destruction rates in the year after entry (firms of age one). This increase in job destruction starts to dominate the increase in start-up activity around 2005, giving rise to a small decrease in employment share for young firms in the business sector. Moreover, we find that most of the job creation by young firms occurs in the expanding service sector.

What can explain this different pattern? We have argued that a likely explanation for the high entrepreneurial activity in the Swedish business sector was a set of policy reforms that were initiated in the late 1980s but mostly implemented in the 1990s. Sweden transformed from having one of the most regulated, static business sectors in the developed world in the late 1980s to one of the more pro-entrepreneurial business regulation systems in the developed world. A potential weakness in the dynamics of the Swedish business sector is the relatively high job destruction rates of firms of age 1 and 2. Moreover, it should also be noted that the reform pace in business policy has substantially slowed in the Swedish business sector the last decades, suggesting that the recent trend of less dynamism in the Swedish business sector might be here to stay.

A welfare analysis of the observed pattern would be of interest. If the different pace of adjustment in Sweden and the US is due to differences in burdensome regulations and institutions, this has potentially large adverse consequences for long-run growth in jobs and productivity. On the other hand, if the driving force is the implementation of ICT, then the welfare consequences will be different. Research along these lines seems warranted.

In our analysis of Sweden, we focused on the total effect of the extensive and wideranging business sector reforms. An interesting avenue for future research would be to examine in greater detail the effects of the different reforms on entrepreneurial activity in the business sector. Moreover, it would be interesting to see whether such reforms in isolation might be sufficient to improve entrepreneurial activity or if it is a package that is needed to create a strong, lasting effect. 


\section{References}

Acemoglu, Daron (2008). "Oligarchic Versus Democratic Societies”. Journal of the European Economic Association 6(1), 1-44.

Acs, Zoltan J. and David B. Audretsch (2005). "Entrepreneurship, Innovation and Technological Change". Foundations and Trends in Entrepreneurship 1(4), 149-195.

Aldén, Lina (2014). Företagande bland utrikes födda-en översikt och en policydiskussion.

Allard, Gayle J. (2005). "Measuring job security over time: in search of a historical indicator for EPL (Employment Protection Legislation)". Working Paper 05-17. Instituto de Empresa, Madrid.

Andersson, Jan and Gunnar Arvidson (2001). Företagens och arbetsställenas dynamik (FAD). Örebro: Statistics Sweden.

Anyadike-Danes, Michael, Carl-Magnus Bjuggren, Sandra Gottschalk, Werner Hölzl, Dan Johansson, Mika Maliranta and Anja Myrann (2015). “An international cohort comparison of size effects on job growth”. Small Business Economics, 44(4), 821-844.

Arrunada, Benito (2007). "Pitfalls to avoid when measuring institutions: Is Doing Business damaging business?”. Journal of Comparative Economics 35(4), 729-47.

Autio, Erkko and Heikki Rannikko (2016). "Retaining winners: Can policy boost highgrowth entrepreneurship?". Research Policy 45(1), 42-55.

Bijnens, Gert and Jozef Konings (2018). “Declining Business Dynamism”. CEPR Discussion Paper No. DP12615.

Branstetter, Lee, Francisco Lima and Lowell J. Taylor (2014). “Do Entry Regulations Deter Entrepreneurship and Job Creation? Evidence from Recent Reforms in Portugal”. Economic Journal 124(577), 805-832.

Braunerhjelm, Pontus and Bo Carlsson (1993). "Entreprenörskap, småföretag och industriell förnyelse 1968-1991”. Research Institute of Industrial Economics (IFN) Working Paper No. 372. IFN, Stockholm.

Bravo-Biosca, Albert, Chiara Criscuolo and Carlo Menon (2016). "What drives the dynamics of business growth?”. Economic Policy 31(88), 703-742. 
Calmfors, Lars (2012). "Sweden: from macroeconomic failure to macroeconomic success". Working Paper 3790, Category 6: Fiscal Policy, Macroeconomics and Growth. CESifo, Munich.

Calvino, Flavino, Chaiara Criscuolo and Carlo Menon (2015). "Cross-country evidence on start-up dynamics”. OECD Science, Technology and Industry Working Papers 2015 (6).

Carroll, Robert, Douglas Holtz-Eakin, Mark Rider and Harvey S. Rosen (2000). "Income taxes and entrepreneurs' use of labor". Journal of Labor Economics, 18(2), 324-351.

Carroll, Robert , Douglas Holtz-Eakin, Mark Rider and Harvey S. Rosen (2001). "Personal income taxes and the growth of small firms". Tax Policy and the Economy, 15, 121-148.

Criscuolo, Chiara, Peter N. Gal and Carlo Menon (2014). "The Dynamics of Employment Growth: New Evidence from 18 Countries”. CEP Discussion Paper, Vol. 1274.

Ciccone, Antonio and Elias Papaioannou (2007). "Red Tape and Delayed Entry". Journal of the European Economic Association 5(2-3), 444-458.

Da Rin, Marco, Marina Di Giacomo, and Alessandro Sembenelli (2011). "Entrepreneurship, firm entry, and the taxation of corporate income: evidence from Europe". Journal of Public Economics, 95(9), 1048-1066.

Davis, Steven J., John Haltiwanger and Scott Schuh (1997). Job Creation and Destruction. Cambridge, MA: MIT Press.

Davis, Steven J. and Magnus Henrekson (2000). 'Wage-setting institutions as industrial policy', NBER Working Paper No. 7502.

Decker, Ryan, John Haltiwanger, Ron Jarmin and Javier Miranda (2014). "The Role of Entrepreneurship in US Job Creation and Economic Dynamism”. Journal of Economic Perspectives 28(3), 3-24.

Decker, Ryan A., John Haltiwanger, Ron S. Jarmin and Jacier Miranda (2016). "Where has all the skewness gone? The decline in high-growth (young) firms in the US". European Economic Review 86, 4-23.

De Loecker, Jan and Jan Eeckhout (2017). "The Rise of Market Power and the Macroeconomic Implications”. Working Paper No. 23687, National Bureau of Economic Research.

Devereux, Michael P., Rachel Griffith, and Alexander Klemm (2002). “Corporate Income Tax Reforms and Tax Competition". Economic Policy 17(35), 449-495. 
Djankov, Simeon, Rafael La Porta, Florencio Lopez-de-Silanes and Andrei Shleifer (2002). “The Regulation of Entry”. Quarterly Journal of Economics 117(1), 1-37.

Djankov, Simeon (2009). “The Regulation of Entry: A Survey”. World Bank Research Observer 24(2), 183-203.

Edquist, Harald, and Magnus Henrekson (2013). "Product market reforms and incentives to innovate in Sweden". In M. Choupres, and H. Edquist, eds., What can we learn from economic reforms in Greece and Sweden? Brussels: European Liberal Forum.

European Commission (2016). The Digital Economy and Society Index.

Färnstrand Damsgaard, Erika, Per Hjertstrand, Pehr-Johan Norbäck, Lars Persson and Helder Vasconcelos (2017). "Why Entrepreneurs Choose Risky R\&D Projects-But Still Not Risky Enough". The Economic Journal 127(605), F164-F199.

Haltiwanger, John, Ron S. Jarmin and Javier Miranda (2013). "Who Creates Jobs? Small Versus Large Versus Young”. The Review of Economics and Statistics 95(2), 347-361.

Hathaway, Ian and Robert Litan (2014). "The Other Aging of America: The Increasing Dominance of Older Firms". Brookings Institution Report July 2014. Washington, D.C.: Brookings Institution.

Henrekson, Magnus and Dan Johansson (1999). "Institutional Effects on the Evolution of the Size Distribution of Firms". Small Business Economics 12(1), 11-23.

Henrekson, Magnus and Dan Johansson (2009). “Competencies and Institutions Fostering High-Growth Firms". Foundations and Trends in Entrepreneurship 5(1), 1-82.

Heyman, Fredrik, Pehr-Johan Norbäck and Lars Persson (2015). "The Turnaround of Swedish Economy: Lessons from Large Business Sector Reforms”. Research Institute of Industrial Economics (IFN) Policy Paper No. 73, forthcoming World Bank Research Observer.

Heyman, Fredrik, Pehr-Johan Norbäck and Lars Persson (2018). "Who Creates Jobs and Who Creates Productivity? Small versus Large versus Young versus Old”. Economics Letters 164 (March), 50-57.

Karahan, Fatih, Benjamin Pugsley, and Aysegul Sahin (2016). "Demographic Origins of the Startup Deficit.” Technical Report. New York Fed, mimeo.

King, Mervyn A. and Don Fullerton (1984). The Taxation of Income from Capital: A Comparative Study of the United States, the United Kingdom, Sweden and West Germany. Chicago: University of Chicago Press. 
Klapper, Leora, Luc Laeven and Raghuram Rajan (2006). "Entry Regulation as a Barrier to Entrepreneurship". Journal of Financial Economics 82(3), 591-629.

Kneller, Richard, and Danny McGowan (2012). "Tax policy and firm entry and exit dynamics: evidence from OECD countries”. Working Papers No. 12006, Bangor Business School, Prifysgol Bangor University (Cymru / Wales).

Lazear, Edward, James Liang and Hui Jackie Wang (2014). "Demographics and Entrepreneurship”. Stanford Graduate School of Business Working Paper No. 4320. Stanford, CA: Stanford Graduate School of Business.

Lindbeck, Assar, Per Molander, Torsten Persson, Olof Petersson, Agnar Sandmo, Birgitta Swedenborg and Niels Thygesen (1994). Turning Around Sweden. Cambridge, MA: MIT Press.

Mason, Colin and Ross Brown (2013). "Creating Good Public Policy to Support High-Growth Firms”. Small Business Economics 40(2), 211-225.

Minniti, Maria (2008). “The Role of Government Policy on Entrepreneurial Activity: Productive, Unproductive, or Destructive?". Entrepreneurship Theory and Practice 32(5), 779-790.

Mthanti, Thanti and Kalu Ojah (2017). "Entrepreneurial orientation (EO): Measurement and policy implications of entrepreneurship at the macroeconomic level". Research Policy 46(4), 724-739.

Neumark, David, Brandon Wall and Junfu Zhang (2011). "Do Small Businesses Create More Jobs? New Evidence for the United States from the National Establishment Time Series". The Review of Economics and Statistics 93(1), 16-29.

Nycander, Svante (2008). Makten över arbetsmarknaden: ett perspektiv på Sveriges 1900-tal, SNS Publishing, Stockholm.

OECD (2014). The Dynamics of Employment Growth. Paris: OECD.

Parker, Simon C. (2007). "Law and the Economics of Entrepreneurship". Comparative Labor Law and Policy Journal 28(4), 695-716.

Perotti, Enrico and Paolo Volpin (2005). “Lobbying On Entry”. CEPR Discussion Paper No. 4519. London: CEPR.

Prantl, Susanne (2012). “The Impact of Firm Entry Regulation on Long-Living Entrants”. Small Business Economics 39(1), 61-76. 
Román, Concepción, Emilio Congregado and José María Millán (2013). “Start-Up Incentives: Entrepreneurship Policy or Active Labour Market Programme?". Journal of Business Venturing 28(1), 151-175.

Santarelli, Enrico and Marco Vivarelli (2007). "Entrepreneurship and the Process of Firms' Entry, Survival and Growth". Industry and Corporate Change 16(3), 455-488.

Shane, Scott (2009). "Why Encouraging More People to Become Entrepreneurs is Bad Public Policy”. Small Business Economics 33(2), 141-149.

Skedinger, Per (2010). Employment protection legislation. Evolution, effects, winners and losers. Northampton, MA: Edward Elgar.

SOU (1993:16). Nya villkor för ekonomi och politik. Stockholm: Allmänna förlaget.

Stenkula, Mikael, Dan Johansson, and Gunnar Du Rietz (2015). "Capital income taxation of Swedish households, 1862 to 2010”. Scandinavian Economic History Review 63 (2) : 15477.

Stigler, George J. (1971). “The Theory of Economic Regulation”. Bell Journal of Economics and Management Science 2(1), 3-21.

Tillväxtanalys (2012). Statligt stöd till näringslivet 2011. Report 2012:05. Östersund: Growth Analysis.

Van Stel, André, David J. Storey and A. Roy Thurik (2007). “The Effect of Business Regulations on Nascent and Young Business Entrepreneurship”. Small Business Economics 28(2), 171-186.

Viscusi, W. Kip, John M. Vernon and Joseph E. Harington (2005). Economics of Regulation and Antitrust. Cambridge, MA: MIT Press.

World Economic Forum (2015). The Global Information Technology Report 2015.

Wölfl, A., I. Wanner, T. Kozluk, and G. Nicoletti (2009). "Ten years of product market reform in OECD countries: insights from a revised PMR indicator”. Working Paper 695. OECD Economic Department, OECD Publishing, Paris.

Zingales, Luigi (2012). A Capitalism for the People. New York, NY: Basic Books. 


\section{Figures}

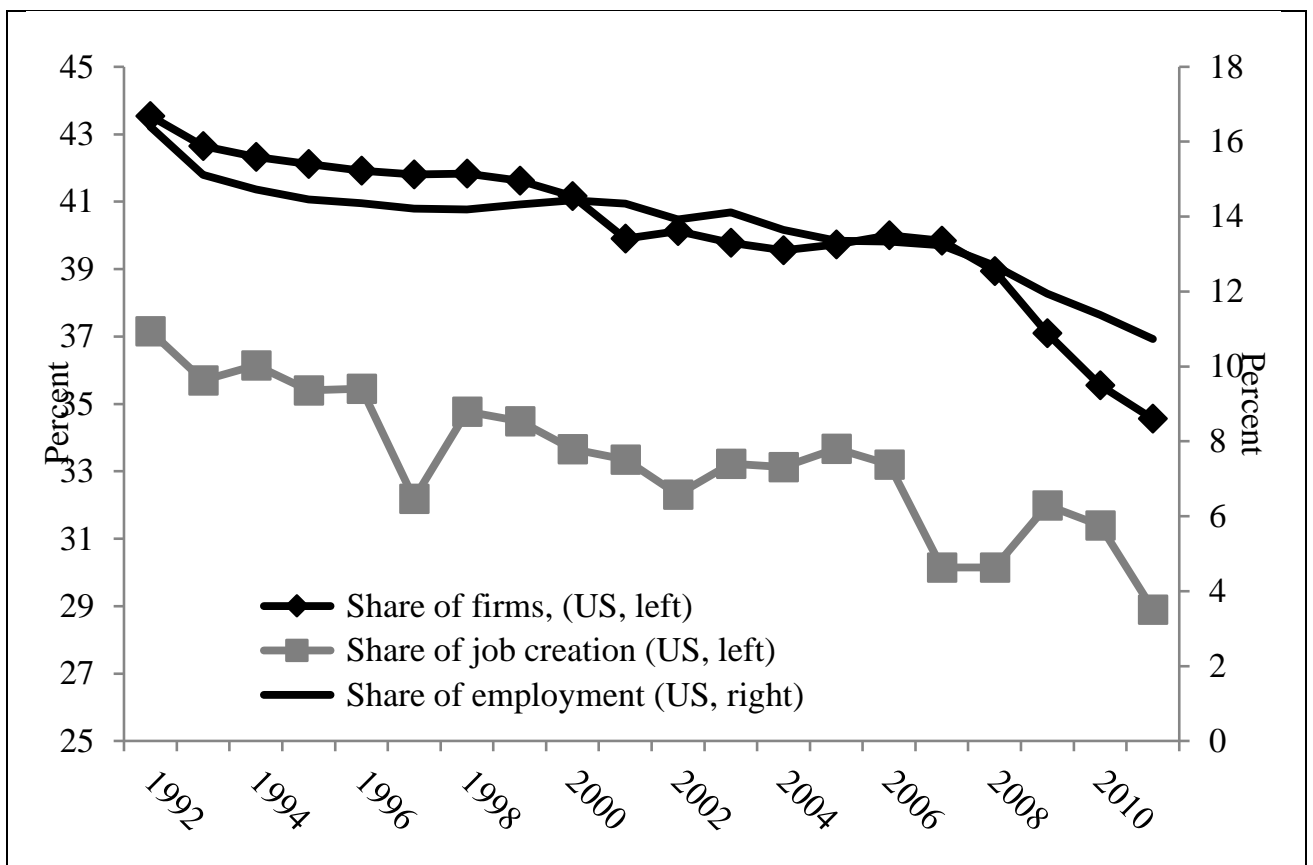

Fig. 1. Declining Share of Activity from Young Firms in the US (firms aged 5 years or less). Firms with at least one employee.

Source: Decker et al. (2014).

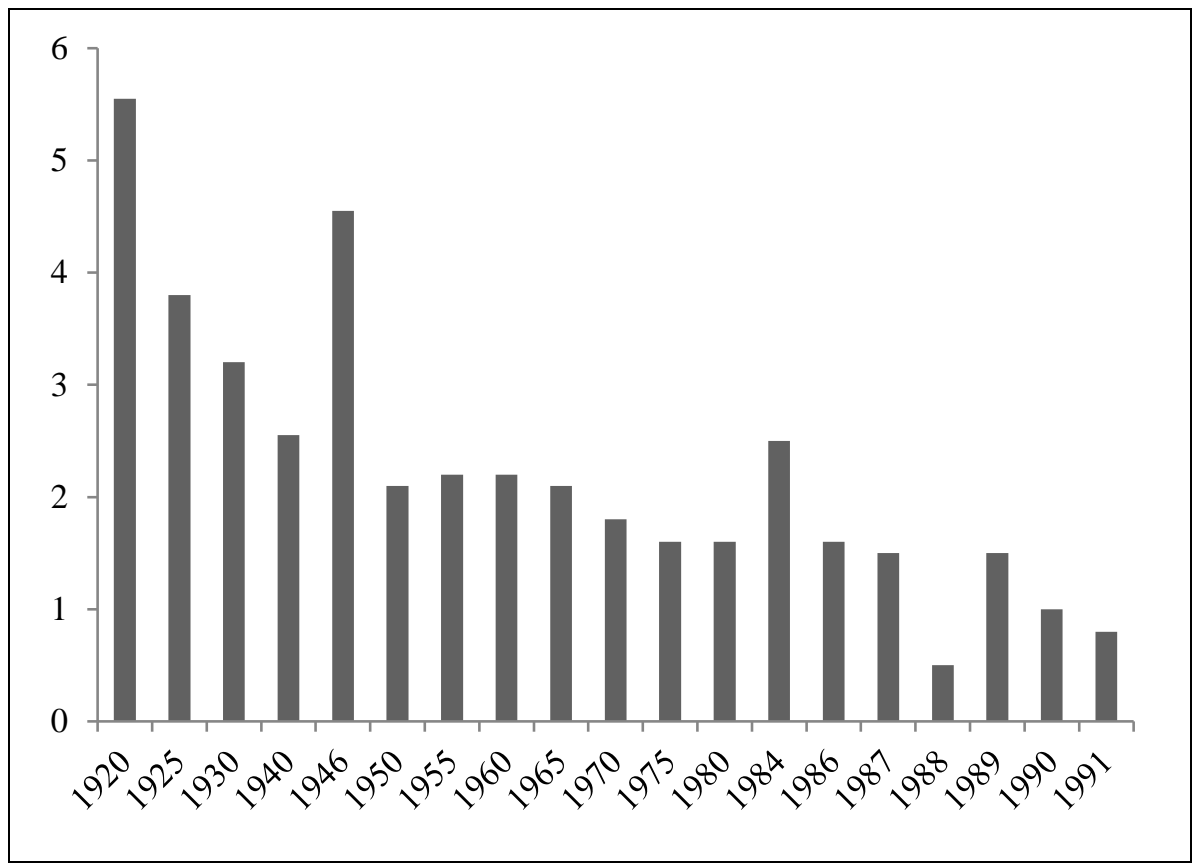

Fig. 2. New Firms in the Swedish Manufacturing Sector (\% of stock). Source: Braunerhjelm and Carlsson (1993) 

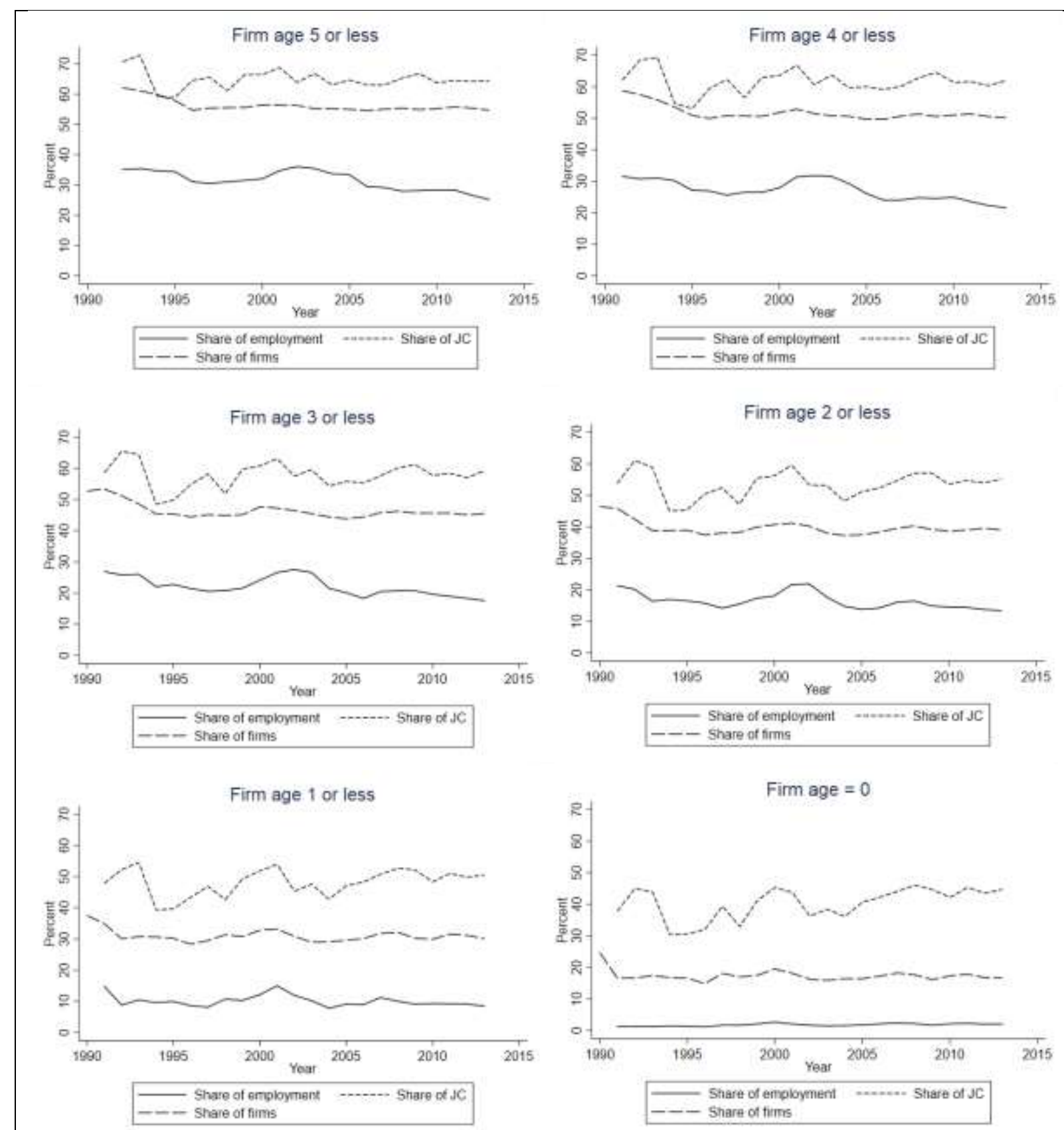

Fig. 3. Share of Activity from Young Firms in Sweden. 

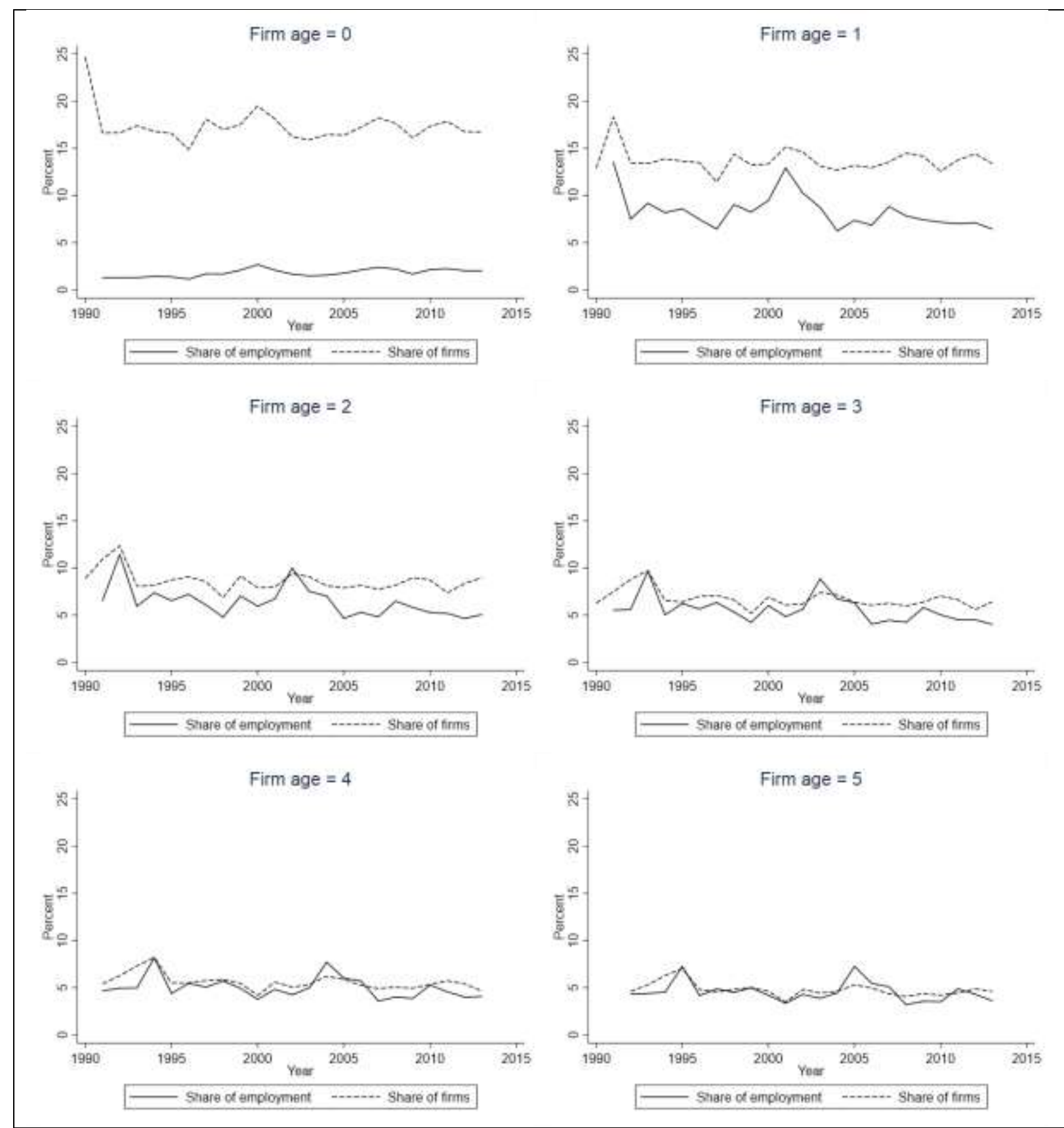

Fig. 4. Share of Activity from Young Firms in Sweden. Share of employment and share of firms by firm age.

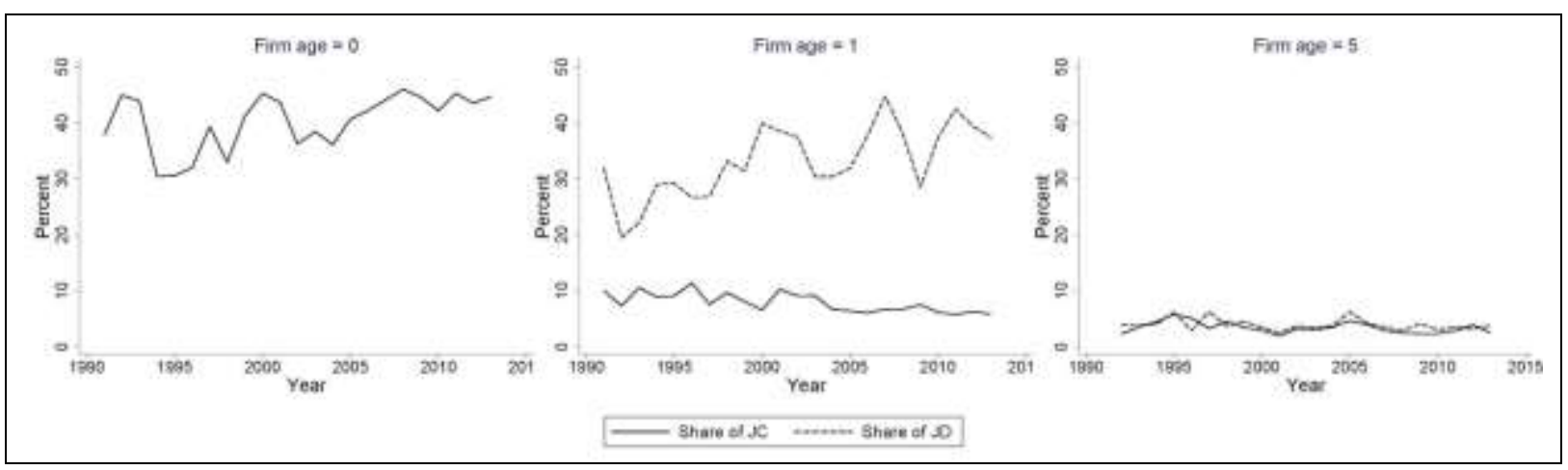

Fig. 5. Share of Activity from Young Firms in Sweden. Share of job creation and job destruction by firm age. 


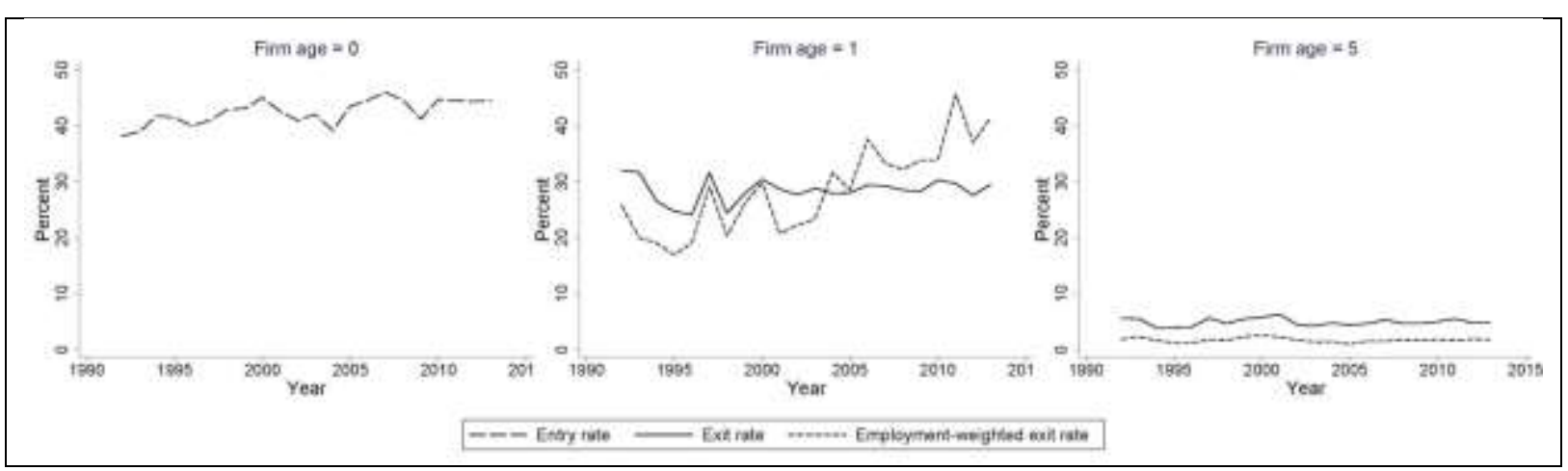

Fig. 6. Annual \& employment-weighted annual firm entry and firm exit rates by firm age.

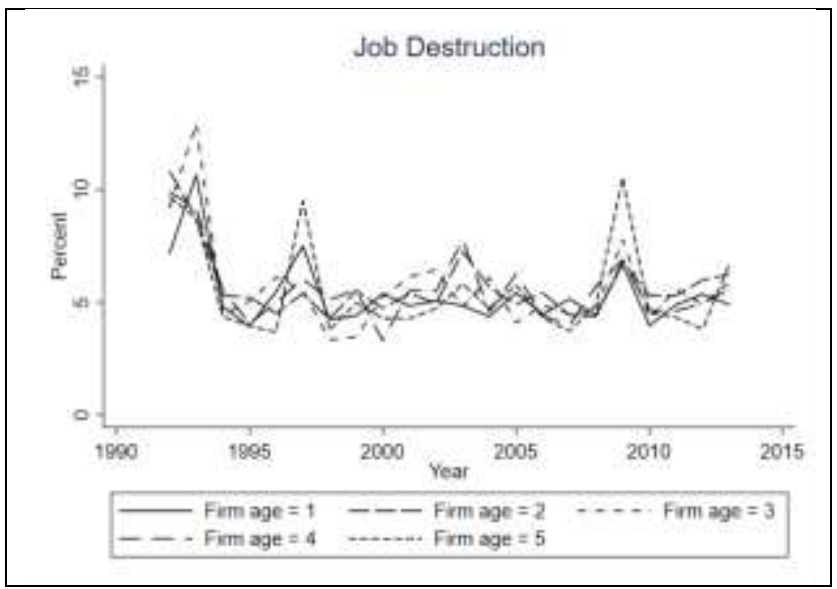

Fig.7. Annual job destruction rates for continuing firms by firm age. 


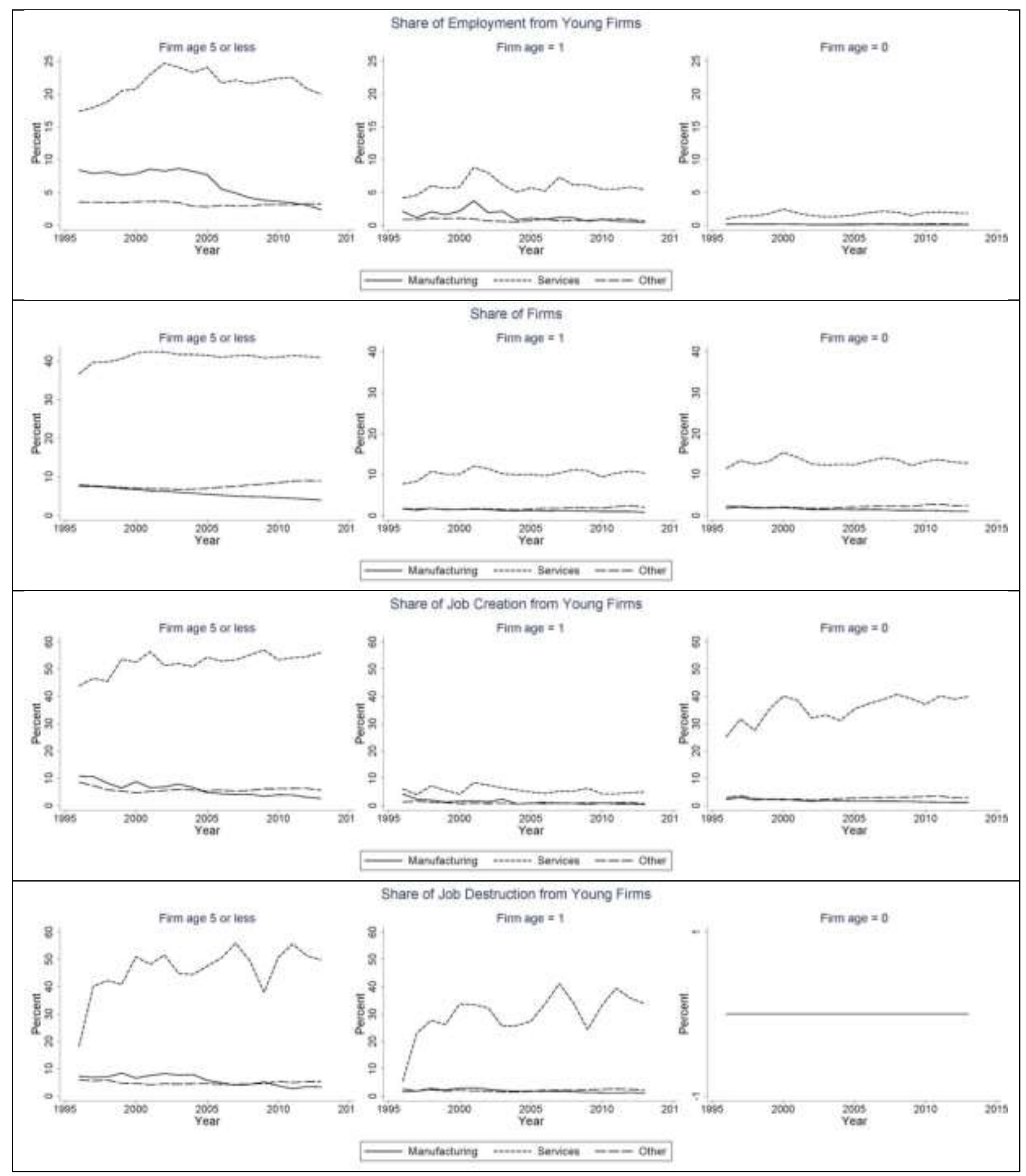

Fig. 8. Share of Activity from Young Firms in Sweden by Sector, 1996-2013. 


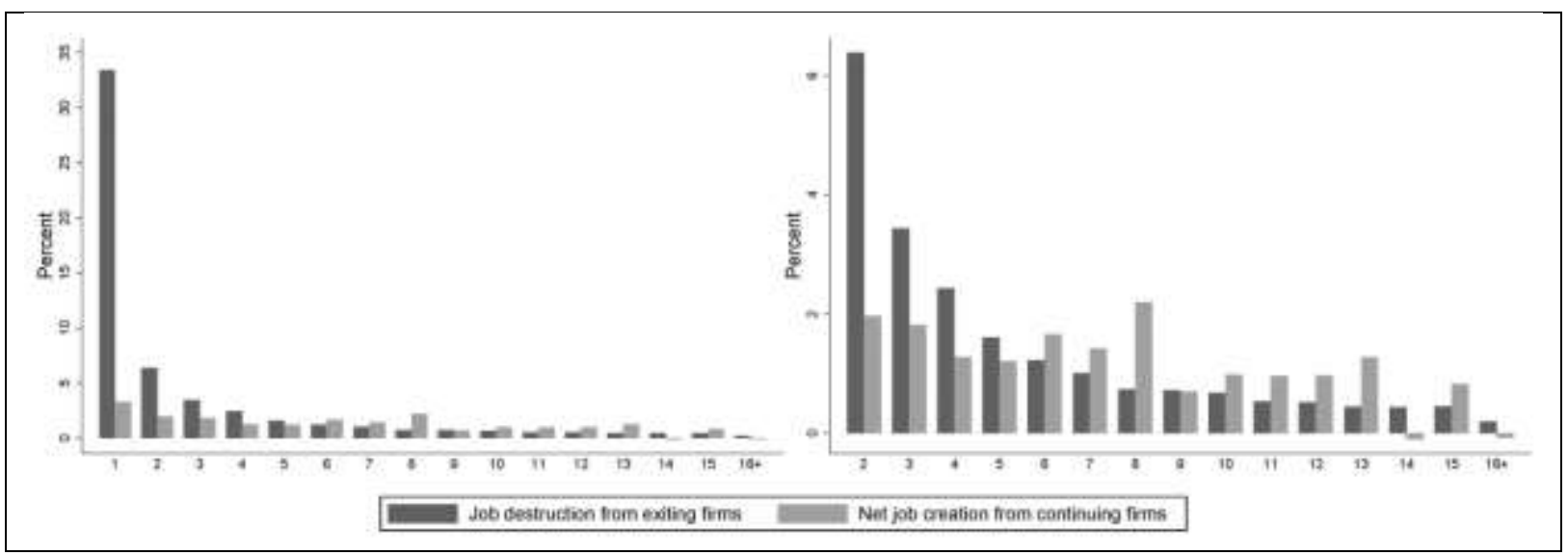

Fig. 9. Up or Out Dynamics for Young Firms in Sweden, 2002-2013.

Note: In the right panel, we exclude firms aged 1 year or less for aesthetic reasons - the rates are much higher than for the remaining groups.

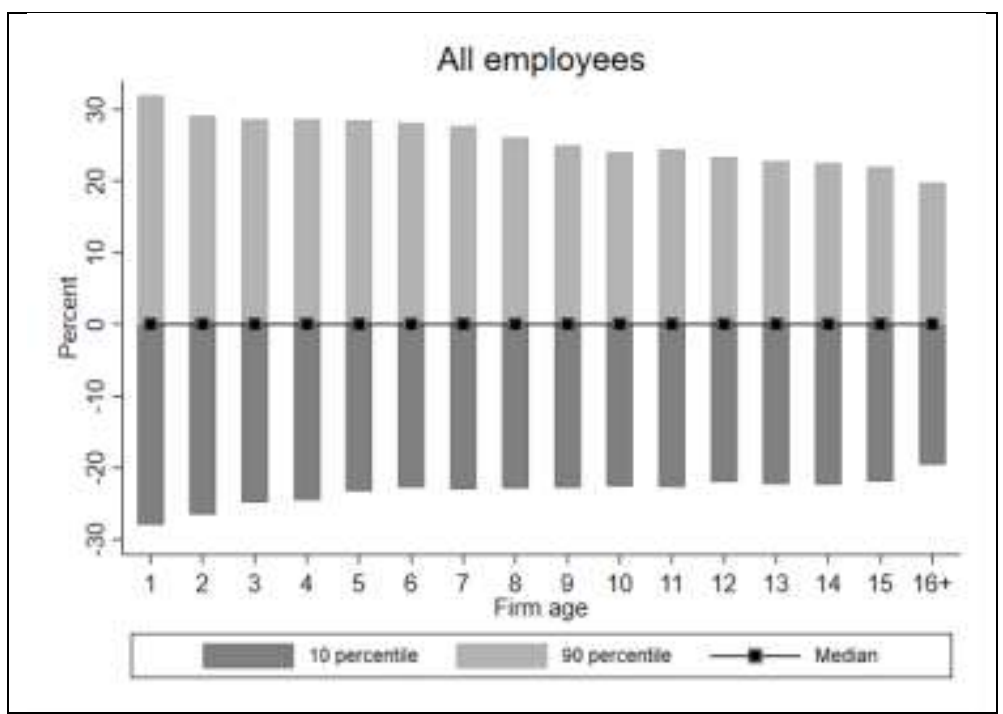

Fig. 10. Net Employment Growth and Growth Rates for Surviving Firms. 


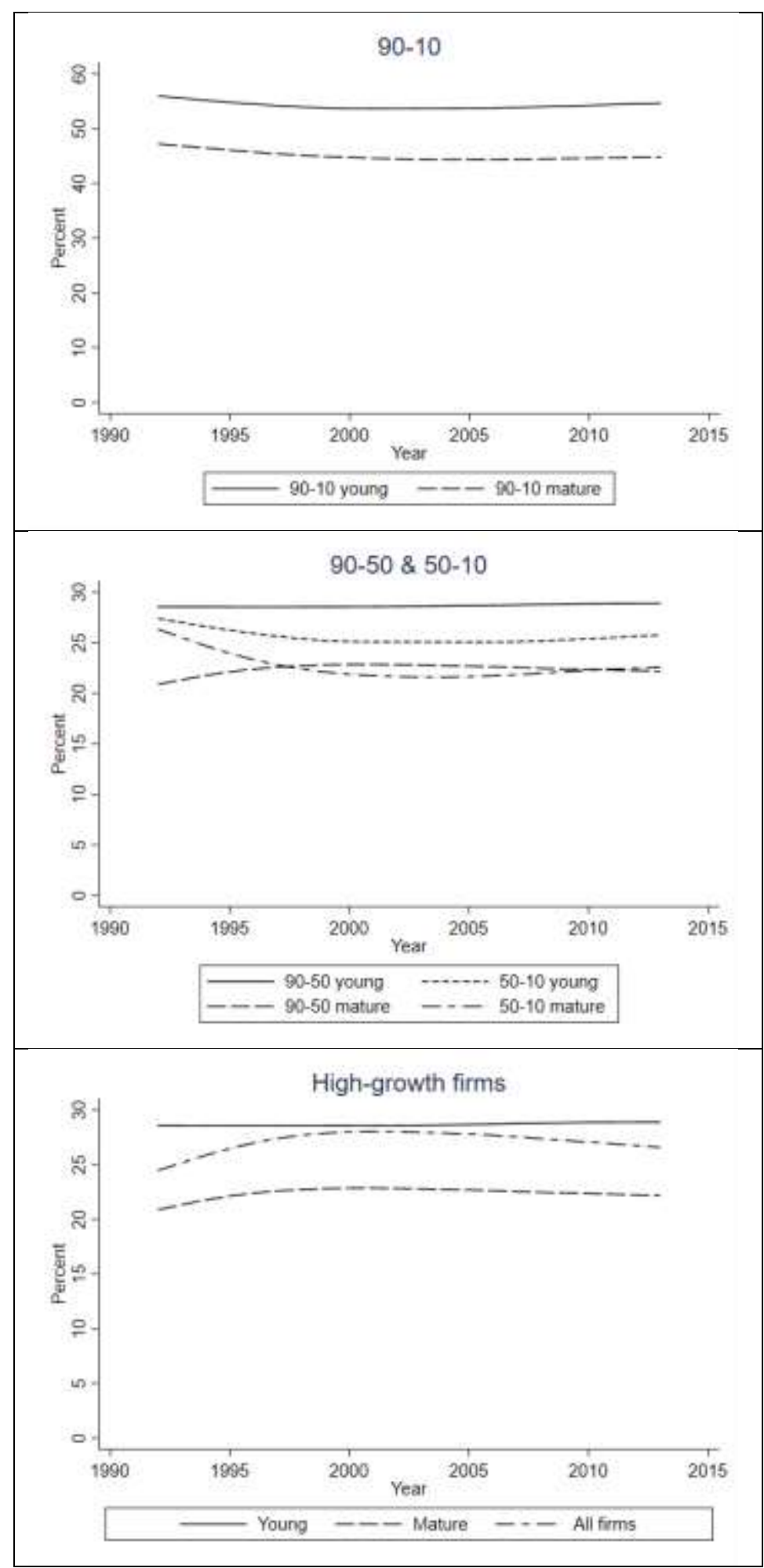

Fig. 11. Firm growth rate differentials and firm growth rates for high-growth firms separated by young and mature firms (employment-weighted).

Note: The 90-10, 90-50 and 50-10 differentials are the difference between 90th and 10th, 90th and 50th and 50th and 10th percentile, respectively. Further, HP trends are used with parameter set to 100. Firm age for young firms is 5 years or less, while mature firms have a firm age of 6 years or more. 


\section{Tables}

Table 1

Net Job Creation by Age and Size, Percentages, 2000-2013.

\begin{tabular}{cccccc}
\hline & & \multicolumn{5}{c}{ Size } \\
Age & $\mathbf{3 - 9}$ & $\mathbf{1 0 - 4 9}$ & $\mathbf{5 0 - 1 9 9}$ & $\mathbf{2 0 0 - 4 9 9}$ & $\mathbf{> 4 9 9}$ \\
\hline & & & & & \\
$0-1$ & 31,42 & 11,89 & 9,86 & 9,14 & 6,93 \\
$2-3$ & $-15,19$ & 0,54 & 1,87 & 1,49 & 0,22 \\
$4-8$ & $-5,27$ & 1,84 & 1,96 & 1,60 & 0,08 \\
$9-13$ & $-3,00$ & 1,57 & 1,21 & 0,81 & 0,30 \\
$>13$ & $-2,48$ & 0,41 & 0,29 & $-0,41$ & $-0,18$ \\
\hline
\end{tabular}

Table 2

Gross Job Creation and Destruction and Net Growth Rate of Firms by Size and Age Groups, 2000-2013.

\begin{tabular}{|c|c|c|c|c|c|c|}
\hline & $\begin{array}{c}\text { (1) } \\
\text { Gross Job } \\
\text { Creation Ratio }\end{array}$ & $\begin{array}{c}\text { (2) } \\
\text { Gross Job } \\
\text { Destruction Ratio } \\
\end{array}$ & $\begin{array}{c}\text { (3) } \\
\text { Net Growth } \\
\text { Rate } \\
\end{array}$ & $\begin{array}{c}\text { (4) } \\
\text { Gross Job } \\
\text { Creation Ratio }\end{array}$ & $\begin{array}{c}\text { (5) } \\
\text { Gross Job } \\
\text { Destruction Ratio } \\
\end{array}$ & $\begin{array}{c}\text { (6) } \\
\text { Net Growth } \\
\text { Rate } \\
\end{array}$ \\
\hline Young & & & & $\begin{array}{c}0.367 * * * \\
(0.000888)\end{array}$ & $\begin{array}{c}0.236 * * * \\
(0.000895)\end{array}$ & $\begin{array}{l}0.131 * * * \\
(0.00141)\end{array}$ \\
\hline Small & $\begin{array}{c}0.213 * * * \\
(0.000933)\end{array}$ & $\begin{array}{c}0.188 * * * \\
(0.000944)\end{array}$ & $\begin{array}{c}0.0249 * * * \\
(0.00145)\end{array}$ & $\begin{array}{l}0.0266 * * * \\
(0.000808)\end{array}$ & $\begin{array}{l}0.0682 * * * \\
(0.000899)\end{array}$ & $\begin{array}{c}-0.0417 * * * \\
(0.00132)\end{array}$ \\
\hline Medium & $\begin{array}{l}0.0387 * * * \\
(0.00115)\end{array}$ & $\begin{array}{l}0.0239 * * * \\
(0.00113)\end{array}$ & $\begin{array}{l}0.0148 * * * \\
(0.00173)\end{array}$ & $\begin{array}{c}-0.0512 * * * \\
(0.00121)\end{array}$ & $\begin{array}{c}-0.0340 * * * \\
(0.00116)\end{array}$ & $\begin{array}{c}-0.0172 * * * \\
(0.00175)\end{array}$ \\
\hline $\begin{array}{l}\text { Observations } \\
\text { R-squared } \\
\text { Year FE }\end{array}$ & $\begin{array}{c}1,484,760 \\
0.006 \\
\text { Yes }\end{array}$ & $\begin{array}{c}1,484,760 \\
0.005 \\
\text { Yes }\end{array}$ & $\begin{array}{c}1,484,760 \\
0.001 \\
\text { Yes }\end{array}$ & $\begin{array}{c}1,484,760 \\
0.108 \\
\text { Yes }\end{array}$ & $\begin{array}{c}1,484,760 \\
0.050 \\
\text { Yes }\end{array}$ & $\begin{array}{c}1,484,760 \\
0.006 \\
\text { Yes }\end{array}$ \\
\hline
\end{tabular}

Notes: The reference categories are Old (age>5) and Large (size 250+). Young-large firms are dropped, as this group is likely to be affected by measurement error. Robust standard errors are in parentheses. $* * * \mathrm{p}<0.01, * * \mathrm{p}<0.05, * \mathrm{p}<0.1$.

\section{Table 3}

Gross Job Creation and Destruction and Net Growth Rate of Firms by Size-Age Groups, 2000-2013.

\begin{tabular}{lccc}
\hline & $(\mathbf{1})$ & $(\mathbf{2})$ & $(\mathbf{3})$ \\
& Gross Job Creation Ratio & Gross Job Destruction Ratio & Net Growth Rate \\
\hline \multirow{2}{*}{ Young $\times$ Small } & & & \\
& $0.398^{* * *}$ & $0.308^{* * *}$ & $0.0909 * * *$ \\
Young $\times$ Medium & $(0.00120)$ & $(0.00117)$ & $(0.00187)$ \\
& $0.120^{* * *}$ & $0.0782^{* * *}$ & $0.0421^{* * *}$ \\
Old $\times$ Small & $(0.00319)$ & $(0.00295)$ & $(0.00462)$ \\
& $0.0218^{* * *}$ & $0.0652^{* * *}$ & $-0.0434 * * *$ \\
Old $\times$ Medium & $(0.000806)$ & $(0.000900)$ & $(0.00132)$ \\
& $0.0122^{* * *}$ & $0.00627 * *$ & $0.00596^{* * *}$ \\
Observations & $(0.000892)$ & $(0.000926)$ & $(0.00141)$ \\
R-squared & $1,484,760$ & $1,484,760$ & $1,484,760$ \\
Year FE & 0.110 & 0.050 & 0.006 \\
\hline
\end{tabular}

Notes: The reference category is Old-Large (age>5; size 250+). Young-large firms are dropped, as this group is likely to be affected by measurement error. Robust standard errors are in parentheses. $* * * \mathrm{p}<0.01, * * \mathrm{p}<0.05, * \mathrm{p}<0.1$. 
Table 4

Gross Job Creation and Destruction and Net Growth Rate of Firms by Size and Age Groups Excluding Entrants, 2000-2013.

\begin{tabular}{|c|c|c|c|c|c|c|}
\hline & $\begin{array}{c}\text { (1) } \\
\text { Gross Job Creation } \\
\text { Ratio }\end{array}$ & $\begin{array}{c}\text { (2) } \\
\text { Gross Job } \\
\text { Destruction Ratio }\end{array}$ & $\begin{array}{c}(3) \\
\text { Net } \\
\text { Growth } \\
\text { Rate } \\
\end{array}$ & $\begin{array}{c}\text { (4) } \\
\text { Gross Job Creation } \\
\text { Ratio }\end{array}$ & $\begin{array}{c}\text { (5) } \\
\text { Gross Job } \\
\text { Destruction Ratio }\end{array}$ & $\begin{array}{c}\text { (6) } \\
\text { Net } \\
\text { Growth } \\
\text { Rate } \\
\end{array}$ \\
\hline Young & & & & $\begin{array}{l}0.0140 * * * \\
(0.000216)\end{array}$ & $\begin{array}{l}0.314 * * * \\
(0.00104)\end{array}$ & $\begin{array}{c}-0.300 * * * \\
(0.00112)\end{array}$ \\
\hline Small & $\begin{array}{l}0.0277 * * * \\
(0.000789)\end{array}$ & $\begin{array}{c}0.213 * * * \\
(0.000970)\end{array}$ & $\begin{array}{c}-0.185 * * * \\
(0.00137)\end{array}$ & $\begin{array}{l}0.0213 * * * \\
(0.000793)\end{array}$ & $\begin{array}{l}0.0695 * * * \\
(0.000904)\end{array}$ & $\begin{array}{c}-0.0482 * * * \\
(0.00132)\end{array}$ \\
\hline Medium & $\begin{array}{l}0.0188 * * * \\
(0.000876)\end{array}$ & $\begin{array}{l}0.0246 * * * \\
(0.00113)\end{array}$ & $\begin{array}{c}-0.0057 * * * \\
(0.00156)\end{array}$ & $\begin{array}{l}0.0155 * * * \\
(0.000875)\end{array}$ & $\begin{array}{c}-0.0497 * * * \\
(0.00120)\end{array}$ & $\begin{array}{c}0.0652 * * * \\
(0.00162)\end{array}$ \\
\hline $\begin{array}{l}\text { Observations } \\
\text { R-squared } \\
\text { Year FE }\end{array}$ & $\begin{array}{c}1,349,168 \\
0.002 \\
\text { Yes }\end{array}$ & $\begin{array}{c}1,349,168 \\
0.006 \\
\text { Yes }\end{array}$ & $\begin{array}{c}1,349,168 \\
0.005 \\
\text { Yes }\end{array}$ & $\begin{array}{c}1,349,168 \\
0.005 \\
\text { Yes }\end{array}$ & $\begin{array}{c}1,349,168 \\
0.078 \\
\text { Yes }\end{array}$ & $\begin{array}{c}1,349,168 \\
0.063 \\
\text { Yes }\end{array}$ \\
\hline
\end{tabular}

Notes: See Table 2

\section{Table 5}

Gross Job Creation and Destruction and Net Growth Rate of Firms by Size-Age Groups Excluding Entrants, 2000-2013.

\begin{tabular}{|c|c|c|c|}
\hline & $\begin{array}{c}\text { (1) } \\
\text { Gross Job Creation Ratio } \\
\end{array}$ & $\begin{array}{c}(2) \\
\text { Gross Job Destruction Ratio } \\
\end{array}$ & $\begin{array}{c}(3) \\
\text { Net Growth Rate }\end{array}$ \\
\hline Young $\times$ Small & $\begin{array}{l}0.0350 * * * \\
(0.000801)\end{array}$ & $\begin{array}{l}0.388 * * * \\
(0.00129)\end{array}$ & $\begin{array}{c}-0.353 * * * \\
(0.00164)\end{array}$ \\
\hline Young $\times$ Medium & $\begin{array}{c}0.0405 * * * \\
(0.00130)\end{array}$ & $\begin{array}{c}0.0835 * * * \\
(0.00306)\end{array}$ & $\begin{array}{c}-0.0431 * * * \\
(0.00354)\end{array}$ \\
\hline Old $\times$ Small & $\begin{array}{l}0.0216 * * * \\
(0.000793)\end{array}$ & $\begin{array}{l}0.0652 * * * \\
(0.000905)\end{array}$ & $\begin{array}{c}-0.0436^{* * * *} \\
(0.00132)\end{array}$ \\
\hline Old $\times$ Medium & $\begin{array}{l}0.0121 * * * \\
(0.000878)\end{array}$ & $\begin{array}{c}0.00631 * * * \\
(0.000931)\end{array}$ & $\begin{array}{c}0.00582 * * * \\
(0.00142)\end{array}$ \\
\hline $\begin{array}{l}\text { Observations } \\
\text { R-squared } \\
\text { Year FE }\end{array}$ & $\begin{array}{c}1,349,168 \\
0.006 \\
\text { Yes } \\
\end{array}$ & $\begin{array}{c}1,349,168 \\
0.080 \\
\text { Yes } \\
\end{array}$ & $\begin{array}{c}1,349,168 \\
0.064 \\
\text { Yes } \\
\end{array}$ \\
\hline
\end{tabular}

Notes: See Table 3. 